\title{
New echinoderm remains in the buried offerings of the Templo Mayor of Tenochtitlan, Mexico City
}

Carolina Martín-Cao-Romero ${ }^{1}$, Francisco Alonso Solís-Marín², Andrea Alejandra Caballero-Ochoa ${ }^{4}$, Yoalli Quetzalli Hernández-Díaz ${ }^{1}$, Leonardo López Luján ${ }^{3} \&$ Belem Zúñiga-Arellano ${ }^{3}$

1. Posgrado en Ciencias del Mar y Limnología, UNAM, México; caromcr@gmail.com, quetzalli.hernandez@gmail.com

2. Laboratorio de Sistemática y Ecología de Equinodermos, Instituto de Ciencias del Mar y Limnología (ICML), Universidad Nacional Autónoma de México, México; fasolis@cmarl.unam.mx

3. Proyecto Templo Mayor (PTM), Instituto Nacional de Antropología e Historia, México (INAH).

4. Facultad de Ciencias, Universidad Nacional Autónoma de México (UNAM), Circuito Exterior s/n, Ciudad Universitaria, Apdo. 70-305, Ciudad de México, México, C.P. 04510; a.caballero.ochoa@gmail.com

Received 01-XII-2016. Corrected 02-V-2017. Accepted 07-VI-2017.

\begin{abstract}
Between 1978 and 1982 the ruins of the Templo Mayor of Tenochtitlan were exhumed a few meters northward from the central plaza (Zócalo) of Mexico City. The temple was the center of the Mexica's ritual life and one of the most famous ceremonial buildings of its time ( $15^{\text {th }}$ and $16^{\text {th }}$ centuries). More than 200 offerings have been recovered in the temple and surrounding buildings. We identified vestiges of 14 species of echinoderms (mostly as disarticulated plates). These include six species of sea stars (Luidia superba, Astropecten regalis, Astropecten duplicatus, Phataria unifascialis, Nidorellia armata, Pentaceraster cumingi), one ophiuroid species (Ophiothrix rudis), two species of sea urchins (Eucidaris thouarsii, Echinometra vanbrunti), four species of sand dollars (Mellita quinquiesperforata, Mellita notabilis, Encope laevis, Clypeaster speciosus) and one species of sea biscuit (Meoma ventricosa grandis). They date back to the reigns of kings Axayacatl (AD 1469-1481), Tizoc (AD 1481-1486), Ahuitzotl (AD 1486-1502), and Motecuhzoma II (AD 1502-1520). Apparently the presence of echinoderms in the offerings is related to the realm of Tlaloc (god of rain and earth). It is believed this organisms, like other marine animals, were used by the priests, like other marine animals, to represent the aquatic underworld of Mesoamerican world-view. Rev. Biol. Trop. 65(Suppl. 1): S168-S179. Epub 2017 November 01.
\end{abstract}

Key words: Echinodermata; Templo Mayor; Tenochtitlan; Mexica Empire; Pre-Hispanic period; Mesoamerica; Mexico.

Animal remains have been part of the archaeological discoveries around the world and are present in different cultures. Archaeozoology is defined as the study of faunal remains left behind when an animal dies on an archaeological site, it includes bones, shells, hair, scales, proteins, and sometimes DNA (Kalof, 2012).

Between 1978 and 1982 the ruins of the Templo Mayor of Tenochtitlan were exhumed a few meters northward from the central plaza (Zócalo) of Mexico City. Over the next few decades, this sacred pyramid was excavated and studied, revealing a wealth of information about Aztec economy, politics, and religion. Five hundred years ago, this multi-tiered pyramid marked the literal center of the Mexica universe, where elaborated ceremonies were performed to maintain cosmic order and sustain the gods (López Austin \& López Luján, 2009, 2017; López Luján, 2001).

After eight long field seasons (1978-2017) at Tenochtitlan's sacred precinct in downtown Mexico City, Templo Mayor archaeological project has recovered more than two hundred offerings dating back to the $14^{\text {th }}, 15^{\text {th }}$ and $16^{\text {th }}$ centuries AD. They were buried by the Mexica priests inside religious buildings and under the 
plaza floors in order to consecrate the enlargements of their temples, to commemorate special festivities, or to appease their gods. Each one of these offerings contained all kinds of gifts, including raw minerals, plants, animals, human remains, and artifacts (López Luján, 2005). As for the animals, several scientists have identified hundreds of species corresponding to six different phyla: Porifera, Coelenterata, Echinodermata, Arthropoda, Mollusca, and Chordata, the latter with six classes (Chondrichthyes, Osteichthyes, Amphibia, Reptilia, Aves and Mammalia). There is a clear predominance of species endemic to regions quite far away from the Basin of Mexico. These were imported by the Mexicas from practically all corners of the empire and beyond, from contrasting ecosystems such as tropical forests, temperate zones, marine environments, estuaries, coastal lagoons, and mangrove swamps. The scarcity of edible species reveals the clear interest on the part of priests in those animals that were attributed with profound religious or cosmological significance (López Luján, Chávez Balderas, Zúñiga-Arellano, Aguirre Molina \& Valentín Maldonado, 2014). In the last few years and thanks to the careful recovery and analysis of all kinds of materials found at the bottom of the offerings, we have identified vestiges of 14 species of echinoderms. These organisms were recovered inside 23 offerings: $1,5,7,57,81,84,88,102,107,120,124,125$, $126,132,136,137,141,143,163,166, \mathrm{M}, \mathrm{N}$, and operation 1 . They date back to the reigns of Axayacatl (AD 1469-1481), Tizoc (AD 1481-1486), Ahuitzotl (AD 1486-1502), and Motecuhzoma II (AD 1502-1520).

\section{MATERIAL AND METHODS}

During its last two field seasons from 2007 to 2017, the Templo Mayor Project explored the area located just at the foot of Tenochtitlan's main pyramid. Until now, 53 offerings have been recovered there. These ritual deposits have yielded tens of thousand of objects that demonstrate not only the enormous religious significance of the area of study, but also the indisputable political and economic power of the Mexica empire. Such a high concentration of riches in such a small space is surprising and has no comparison in similar contexts from the Olmec, Maya, and Teotihuacan cultures.

This investigation began with the recurring discovery in our excavations of some echinoderm remains (varying from complete echinoid tests, fragments, disarticulated spines, and also diversely-shaped sea stars calcareous plates). Nearly all of them were concentrated inside the stone offering boxes and associated with marine organisms such as bivalves, gastropods, and corals.

After being photographed, drawn, and described in their original contexts, all these echinoderm remains were collected using plastic bags, labeled, and recorded in a data base. Later, they were carefully cleaned in the field laboratory and counted. Then they were separated according to their differential morphology. We distinguished various anatomic segments of the endoskeleton, which enabled us to begin the taxonomic identifications.

In order to identify the organisms to which these elements belonged, we compared our archaeological remains to modern specimens collected in Mexican waters and stored in the Echinoderm National Collection (ENC) ICML, UNAM (Table 1). Organisms were observed using both an optic microscope and scanning electron microscope (SEM) imaging. In order to observe the skeleton of the sea stars the skin was removed with regular household bleach $(\mathrm{NaClO})$, after that the individual skeletal plates were extracted from specimens or parts of specimen immersed, rinsed in tap water, dried, mounted on aluminium stubs and goldcoated (modified from Thuy \& Stöhr, 2016).

Pictures of taxonomical characters of the species were taken with a multifocal microscope AXIO Zoom.V16 with the camera AxioCam MRc5 and the program Zeiss Efficient Navigation, at the Microscope Laboratory (Instituto de Biología, UNAM).

To determine the size of the major radius ( $\mathrm{R}=$ distance from the center of the disc to the tip of one of the arms) of Nidorellia armata 
TABLE 1

Odontophore size, major radius (R) and catalogue number of Nidorellia armata specimens deposited at the Echinoderm National Collection, UNAM, collected between the years 1947 and 1991

\section{CUADRO 1}

Tamaño del odontóforo, radio mayor (R) y número de catálogo de los especímenes de Nidorellia armata depositados en la Echinoderm National Collection,

UNAM, colectados entre los años 1947 y 1991

\begin{tabular}{ccc}
$\begin{array}{c}\text { Odontophore } \\
(\mathrm{mm})\end{array}$ & $\mathrm{R}(\mathrm{mm})$ & $\begin{array}{c}\text { Catalogue number } \\
\text { (ICML-UNAM) }\end{array}$ \\
\hline 2.39 & 23.24 & 11142 \\
3.55 & 38.80 & 11142 \\
3.59 & 38.77 & 10036 \\
3.61 & 39.85 & 10036 \\
3.71 & 39.91 & 2.40 .22 \\
3.96 & 38.55 & 2.40 .24 \\
4.1 & 40.02 & 2.40 .25 \\
4.16 & 36.36 & 2.40 .3 \\
4.32 & 37.75 & 2.40 .3 \\
4.41 & 46.74 & 2.40 .21 \\
4.63 & 60.95 & 2.40 .11 \\
4.75 & 44.39 & 2.40 .11 \\
5.09 & 57.09 & 2.40 .16 \\
5.13 & 55.82 & 2.40 .16 \\
5.34 & 51.76 & 2.40 .9 \\
5.61 & 54.77 & 2.40 .23 \\
5.96 & 66.6 & 2.40 .9 \\
6.10 & 59.25 & 2.40 .9 \\
6.18 & 67.79 & 2.40 .0 \\
6.21 & 48.46 & 2.40 .1 \\
6.62 & 57.9 & 2.40 .15 \\
6.85 & 60.99 & 2.40 .4 \\
6.93 & 65.95 & 2.40 .5 \\
7.19 & 71.60 & 2.40 .1 \\
7.89 & 66.78 & 2.40 .1 \\
8.01 & 74.35 & 2.40 .1 \\
8.05 & 82.58 & 2.40 .1 \\
8.06 & 75.48 & 2.40 .1 \\
8.27 & 71.5 & 2.40 .37 \\
8.28 & 64.78 & 2.40 .37 \\
8.37 & 61.01 & 2.40 .13 \\
8.55 & 73.71 & 2.40 .7 \\
8.73 & 86.04 & 2.40 .7 \\
\hline .12 & 75.38 & \\
\hline & & 2.40 .18 \\
\hline
\end{tabular}

specimens buried in the offerings, we measure the wide of the odontophore (plaque on which the teeth are found in the sea stars) and related

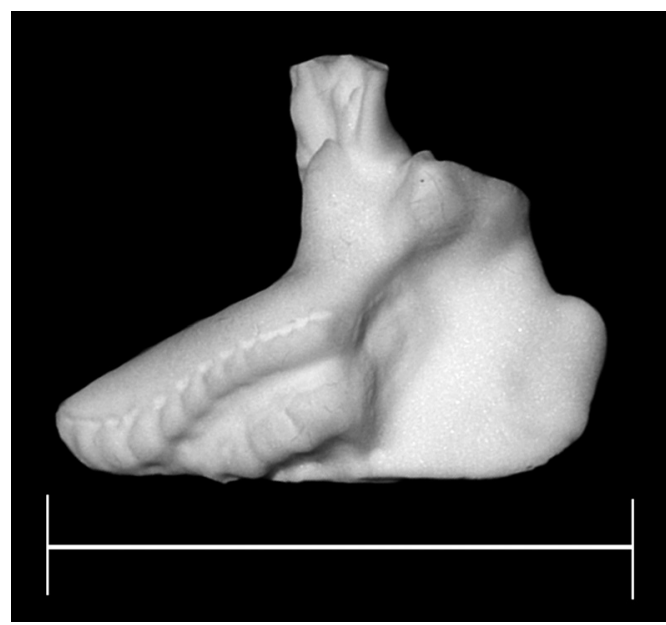

Fig. 1. Width size sea star odontophore measurement. Fig. 1. Medida del ancho del odontóforo de la estrella de mar.

it to the measurement of the major radius $(\mathrm{R})$ (Fig. 1). For the comparative data, we measured 35 modern organisms deposited in the ENC, ICML, UNAM and 39 odontophores from the ancient offerings. Extrapolation of these data was used to estimate the major radius (R) of the specimens buried five hundreds years ago.

Given the success of our studies, we decided to widen the investigation to include the Templo Mayor Museum, to see if there were any other echinoderm remains in the collections from earlier field seasons of the Templo Mayor Project (1978-1982, 1987 and 1989). In the storage facilities we found several bags of sediment from seven offerings, which contained more echinoderm fragments and plates.

\section{RESULTS}

We identified vestiges of 14 species of echinoderms. These organisms were recovered inside offerings $1,5,7,11,17,57,81,84$, $88,102,107,120,124,125,126,132,136$, $137,141,143,163,166, \mathrm{M}, \mathrm{N}$, and operation 1 (phases IVb-VII, AD 1469-1520). They date from the period when Tenochtitlan was governed successively by Axayacatl, Tizoc, Ahuitzotl, and Motecuhzoma II. The majority 
of the echinoderm elements found at the offerings comprises disarticulated plates, since their structures tend to disintegrate in the ground over the centuries. These include six species of sea stars (Luidia superba, Astropecten regalis, Astropecten duplicatus, Nidorellia armata, Pentaceraster cumingi, Phataria unifascialis), one ophiuroid species (Ophiothrix rudis), two species of sea urchins (Eucidaris thouarsii, Echinometra vanbrunti), four species of sand dollars (Mellita quinquiesperforata, Mellita notabilis, Encope laevis, Clypeaster speciosus), and one species of sea biscuit (Meoma ventricosa grandis). Complete tests, spines and fragments of both irregular and regular sea urchins have been found; sea stars' disarticulated plates are predominant in the offerings, and only one complete segment of an arm tip of Astropecten duplicatus has been found.

\section{Systematics}

List of echinoderm species found in the Templo Mayor offerings:

Phyum Echinodermata Bruguière, 1791

Class Asteroidea Blainville, 1830

Order Paxillosida Perrier, 1884

Family Luidiidae Sladen, 1889

Genus Luidia Forbes, 1839

Luidia superba A. H. Clark, 1917

Genus Astropecten Gray 1840

Astropecten regalis Gray 1840

Astropecten duplicatus Gray 1840

Order Valvatida Perrier 1884

Family Ophidiasteridae Verrill 1870

Genus Phataria Gray 1840

Phataria unifascialis Gray 1840

Family Oreasteridae Fisher 1911

Genus Nidorellia Gray, 1840

Nidorellia armata (Gray, 1980)

Genus Pentaceraster Döderlein, 1916

Pentaceraster cumingi (Gray, 1980)

Class Ophiuroidea Gray, 1840

Order Ophiurida Müller \& Troschel, 1840

Family Ophiotrichidae Ljungman, 1866

Genus Ophiothrix Müller \& Troschel, 1840

Ophiothrix rudis Lyman, 1874
Class Echinoidea Leske, 1778

Order Cidaroida Claus, 1880

Family Cidaridae Gray, 1825

Genus Eucidaris Pomel, 1883

Eucidaris thouarsii (L. Agassiz \& Désor, 1846)

Order Camarodonta Jackson, 1912

Family Echinometridae Gray, 1825

Genus Echinometra Gray, 1825

Echinometra vanbrunti A. Agassiz, 1863

Order Clypeasteroida A. Agassiz, 1872

Family Clypeasteridae L. Agassiz, 1835

Genus Clypeaster Lamarck, 180124

Clypeaster speciosus Verrill, 1870

Family Mellitidae Stefanini, 1912

Genus Encope L. Agassiz, 1840

Encope laevis H. L. Clark, 1948

Genus Mellita L. Agassiz, 1841

Mellita notabilis H. L. Clark, 1947

Mellita quinquiesperforata (Leske, 1778)

Order Spatangoida L. Agassiz, 1840

Family Brissidae Gray, 1855

Genus Meoma Gray, 1851

Meoma ventricosa grandis Gray, 1851

Luidia superba (Fig. 2). The presence of this species in the offerings is rare, around 20 skeletal plates have been found in two offerings: 126 and 137. This species today, this species has a geographic distribution from the Gulf of California to the south Mexican Pacific coast; Panamá (Alvarado, Solís-Marín, \& Ahearn, 2010); Colombia and Galapagos Islands; its bathymetric distribution goes from 3 to $250 \mathrm{~m}$. It has been found in muddy, sandy or rubble substrates (Pérez-Ruzafa, Alvarado, Solís-Marín, Hernández, Morata, Marcos, ... \& Barraza, 2013).

Astropecten duplicatus (Fig. 3). The presence of this species in the offerings is very rare, around 30 fragments have been found (offering 126) (González López, López Luján, MartínCao Martínez, Solís-Marín, \& Zúñiga-Arellano, et al., 2011). Today, this species has a geographic distribution from North Carolina, USA, to the north of Brazil; its bathymetric distribution goes from 0 to $550 \mathrm{~m}$ (Clark \& Downey, 1992). It has been found in muddy, rocky or sandy substrates (Pérez-Ruzafa et al., 2013). 


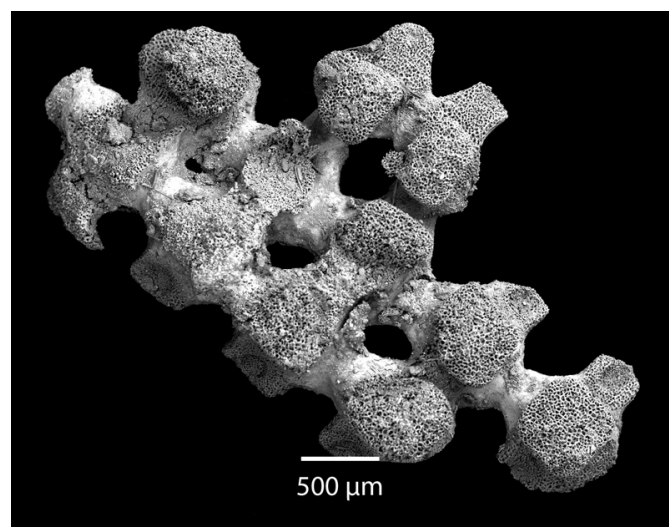

Fig. 2. Luidia superba (archaeological specimen). Articulated abactinal plates scanning electro microscope.

Fig. 2. Luidia superba (espécimen arqueológico). Microscopía electrónica de barrido de placas abactinales articuladas.

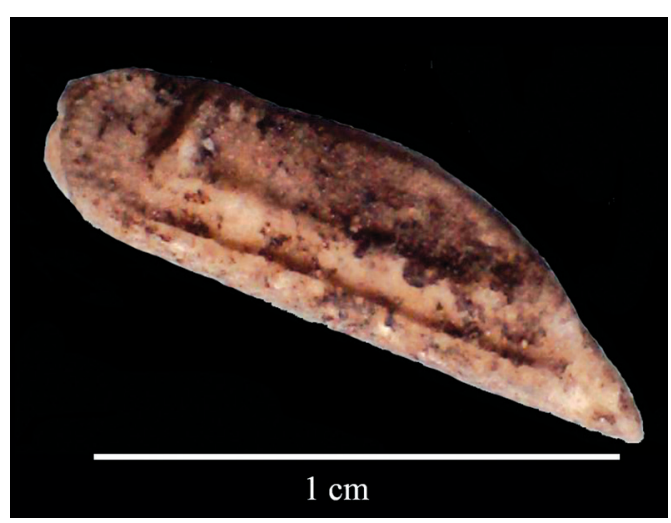

Fig. 3. Astropecten duplicatus (archaeological specimen). Marginal plate.

Fig. 3. Astropecten duplicatus (espécimen arqueológico). Placa marginal.

Astropecten regalis (Fig. 4). This species has been found in six offerings $(84,100,101$, 103, 126 and 163), and around 1200 plates have been excavated. This species actually has a geographic distribution from the Gulf of California to the south Mexican Pacific coast, El Salvador, Nicaragua, Costa Rica, Panama and Colombia. It has a bathymetric distribution from 0 to $204 \mathrm{~m}$. It has been found in muddy, sandy, sea grass or rubble substrates (PérezRuzafa et al., 2013).

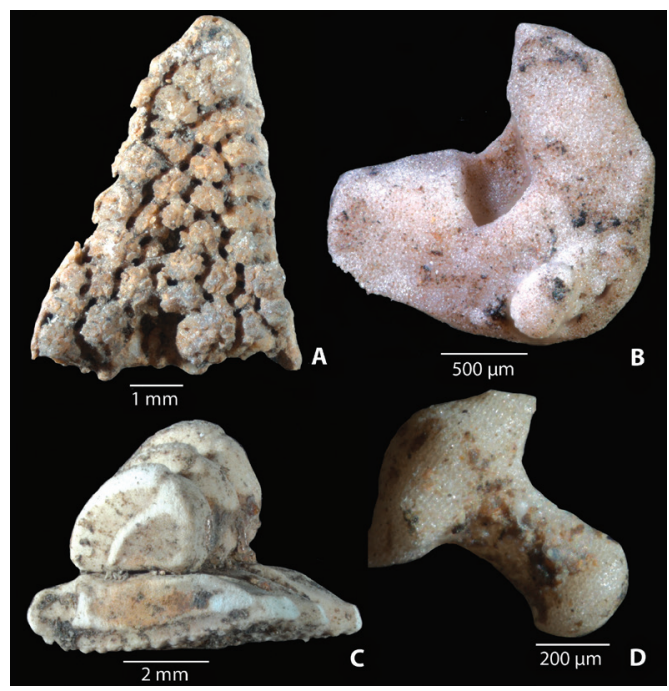

Fig. 4. Astropecten regalis (archaeological specimen). A. Tip of an articulated arm; B. Terminal plate; C. Infero and superomarginal articulated plates; D. Paxillae column.

Fig. 4. Astropecten regalis (espécimen arqueológico). A. Punta de brazo articulado; B. Placa terminal; C. Placas ínfero y súperomariginales articualdas; D. Columna de paxila.

Phataria unifascialis (Fig. 5). The presence of this species in the offerings is very rare, only 28 skeletal elements have been found in three offerings $(84,100$ and $N)$. Today, this species has a geographic distribution from the Gulf of California to Peru, with a bathymetric distribution from 0 to $50 \mathrm{~m}$. It has been found in coral reefs, on rocky or sandy substrates (Pérez-Ruzafa et al., 2013).

Nidorellia armata (Fig. 6). The presence of this species in the offerings is fairly common (around 40000 skeletal elements have been found), and it was discovered in 20 offerings (Chamber 1, and offerings 7, 81, 84, 88, 100, $101,102,103,124,125,126,132,136,137$, 143, 163 166, M and N). Today, this species has a geographic distribution from the Gulf of California to the south Mexican Pacific coast, El Salvador, Nicaragua, Costa Rica, Panama, Colombia, Ecuador, Galapagos Islands, and Peru. It has a bathymetric distribution from 0 to $183 \mathrm{~m}$. It has been found in coral reefs, rocky or rubble substrates (Pérez-Ruzafa et al., 2013). The size of some of the skeletal plates (i.e. 


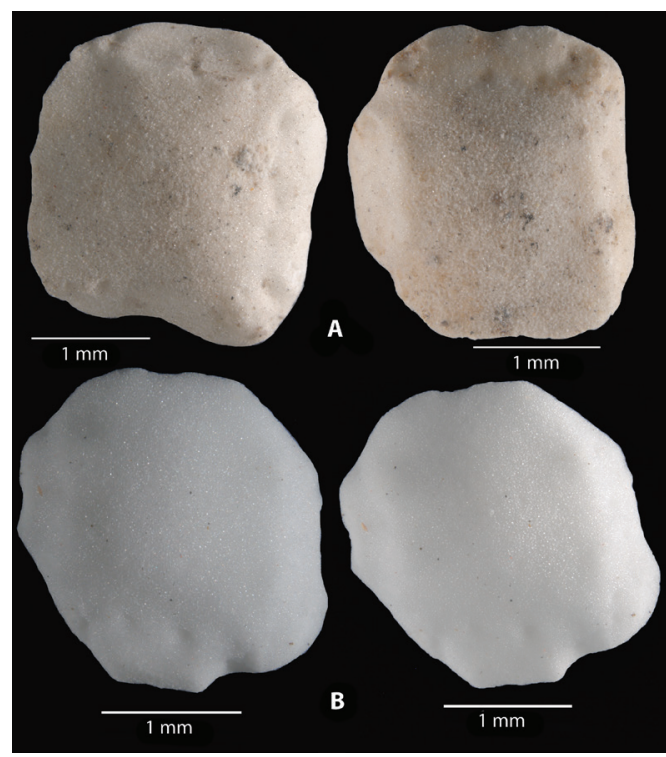

Fig. 5. Phataria unifascialis. A. Archaeological specimen, carinal plates; B. Non Archaeological specimen, carinal plates.

Fig. 5. Phataria unifascialis. A. Espécimen arqueológico, placas carinales; B. Espécimen no arqueológico, placas carinales.

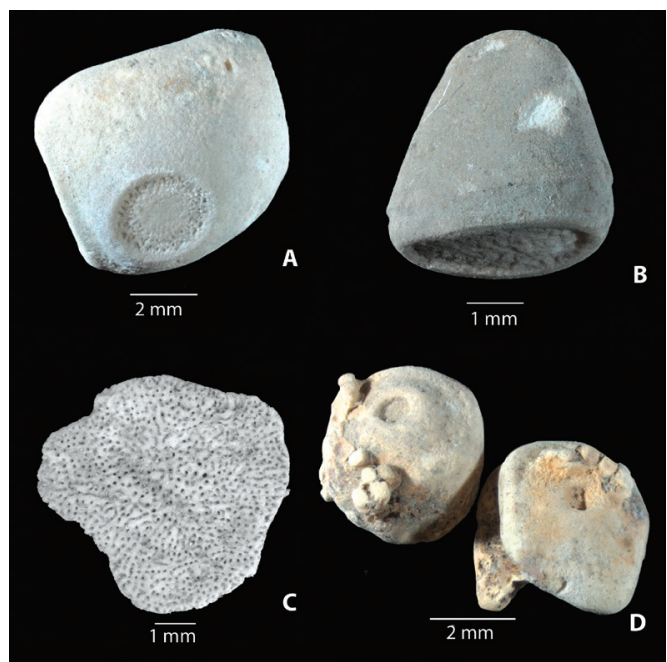

Fig. 6. Nidorellia armata (archaeological specimen). A. Marginal plate; B. Marginal spine; C. Madreporite plate; D. Abactinal plates.

Fig. 6. Nidorellia armata (espécimen arqueológico). A. Placa marginal; B. Espina marginal; C. Placa madrepórica; D. Placas abactinales.

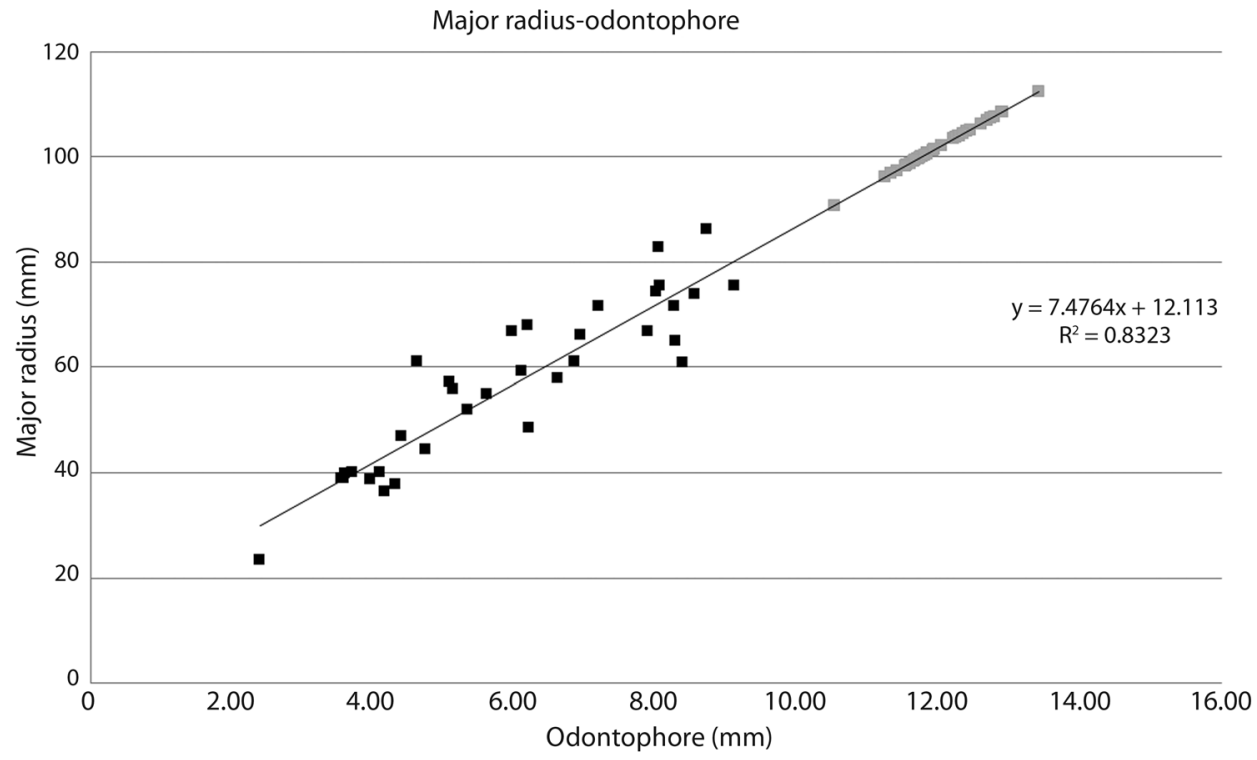

Fig. 7. Nidorellia armata odontophore width size versus arm major radius (R). ( $\square)$ : Archaeological specimens; $(\square)$ : nonarchaeological specimens.

Fig. 7. Nidorellia armata medida del ancho del odontóforo contra radio mayor (R). ( $\square$ ): Especímenes arqueológicos; (ם):Especímenes no arqueológicos. 
odonthophores) found in the offerings (Table 2) led us to believe that this species' remains correspond to "bigger" organisms of much greater sizes than those found on our shores today; the size of the biggest odontophore of the specimen originally buried was $16.57 \mathrm{~mm}$, which corresponds in the comparative graphic to a $\mathrm{R}$ of $135.99 \mathrm{~mm}$. This is surprisingly big in comparison with specimens held at the ENC, ICML, UNAM whose R value does not exceed $87 \mathrm{~mm}$ (Fig. 7).

Pentaceraster cumingi (Fig. 8). The presence of this species in the offerings is common (10000 elements have been found in 13 offerings: $81,84,100,101,103,124,126,136,137$, 143, 163, M and N), but less abundant than $N$. armata. Today, it has a geographic distribution from the Gulf of California to the south Mexican Pacific coast, Costa Rica, Panama, Colombia, Galapagos Islands, and Peru, with a bathymetric distribution from 2 to $92 \mathrm{~m}$. It has been found in coral reefs, rocky or sandy bottoms (Pérez-Ruzafa et al., 2013).

Ophiothrix rudis (Fig. 9). The presence of this species in the offerings is very rare (only eight small spines have been found in offering 126). Today it has a geographic distribution from California, USA, to the Mexican Pacific coast, with a bathymetric distribution from 0 to $1 \mathrm{~m}$. It has been found on rocky, coral reefs or sandy substrates (Pérez-Ruzafa et al., 2013).

Eucidaris thouarsii (Fig. 10). The presence of this species in the offerings is very rare (only one fragmented primary spine has been found in offering 1). Today it has a geographic

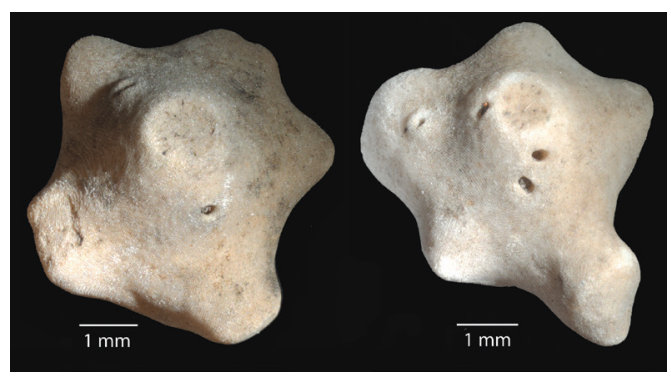

Fig. 8. Pentaceraster cumingi (archaeological specimen). Abactinal plates.

Fig. 8. Pentaceraster cumingi (espécimen arqueológico). Placas abactinales.
TABLE 2

Nidorellia armata odontophore size from specimen originally buried at the Templo Mayor offerings and estimation of their major radius $(\mathrm{R})$

CUADRO 2

Tamaño del odontóforo de los especímenes de Nidorellia armata originalmente enterrados como ofrendas en el Templo Mayor y una estimación de su radio mayor

\begin{tabular}{|c|c|c|}
\hline $\begin{array}{l}\text { Odontophore } \\
\text { (mm) }\end{array}$ & $\begin{array}{l}\text { R estimated } \\
(\mathrm{mm})\end{array}$ & $\begin{array}{l}\text { Offering } \\
\text { number }\end{array}$ \\
\hline 10.52 & 90.76 & 102 \\
\hline 11.24 & 96.14 & 102 \\
\hline 11.32 & 96.74 & 102 \\
\hline 11.33 & 96.82 & 102 \\
\hline 11.41 & 97.41 & 103 \\
\hline 11.53 & 98.31 & 102 \\
\hline 11.55 & 98.46 & 102 \\
\hline 11.59 & 98.76 & 102 \\
\hline 11.64 & 99.13 & 103 \\
\hline 11.66 & 99.28 & 103 \\
\hline 11.66 & 99.28 & 102 \\
\hline 11.69 & 99.51 & 103 \\
\hline 11.71 & 99.66 & 103 \\
\hline 11.73 & 99.81 & 102 \\
\hline 11.75 & 99.96 & 102 \\
\hline 11.77 & 100.11 & 103 \\
\hline 11.77 & 100.11 & 103 \\
\hline 11.8 & 100.33 & 102 \\
\hline 11.83 & 100.55 & 102 \\
\hline 11.84 & 100.63 & 103 \\
\hline 11.92 & 101.23 & 102 \\
\hline 11.93 & 101.3 & 103 \\
\hline 11.93 & 101.3 & 100 \\
\hline 12.03 & 102.05 & 103 \\
\hline 12.03 & 102.05 & 102 \\
\hline 12.21 & 103.39 & 103 \\
\hline 12.24 & 103.62 & 103 \\
\hline 12.27 & 103.84 & 103 \\
\hline 12.29 & 103.99 & 102 \\
\hline 12.35 & 104.44 & 102 \\
\hline 12.4 & 104.82 & 103 \\
\hline 12.44 & 105.11 & 102 \\
\hline 12.6 & 106.31 & 102 \\
\hline 12.68 & 106.91 & 100 \\
\hline 12.73 & 107.28 & 102 \\
\hline 12.78 & 107.66 & 102 \\
\hline 12.89 & 108.48 & 102 \\
\hline 12.9 & 108.55 & 103 \\
\hline 13.41 & 112.37 & 102 \\
\hline
\end{tabular}




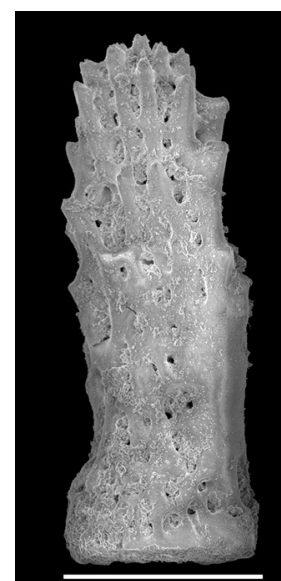

$100 \mu \mathrm{m}$

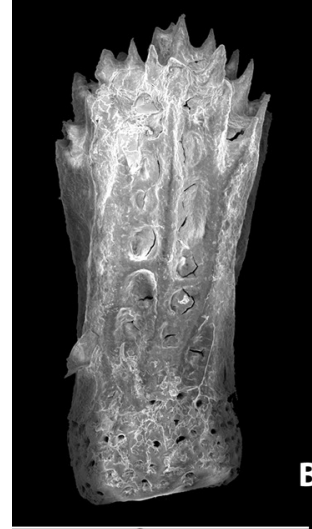

$200 \mu \mathrm{m}$

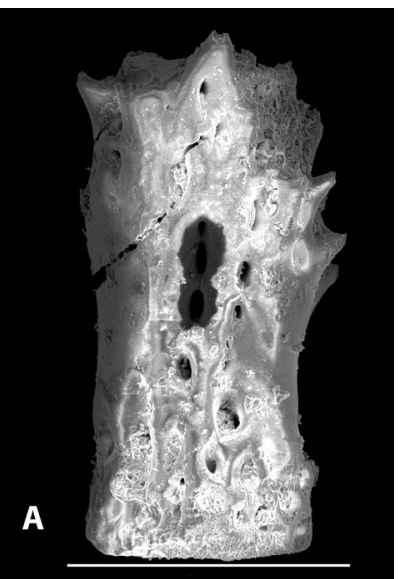

$100 \mu \mathrm{m}$

B

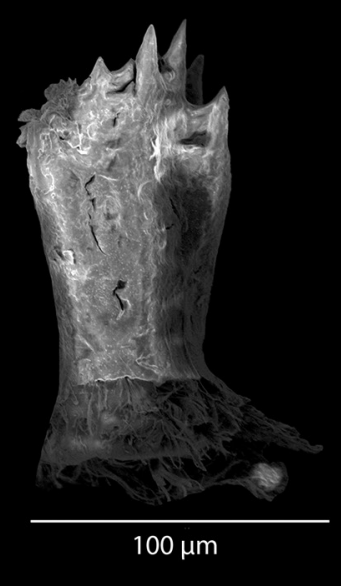

Fig. 9. Ophiothrix rudis. A. Disc spines of an archaeological specimen; B. Disc spines of a non-archaeological specimen. Fig. 9. Ophiothrix rudis. A. Espinas del disco de un espécimen arqueológico; B. Espinas del disco de un espécimen no arqueológico.

distribution from California, USA, to the Mexican Pacific coast, Panama and Ecuador, with a bathymetric distribution from 0 to $150 \mathrm{~m}$. It has been found in coral reefs, muddy, rocky or sandy substrates (Pérez-Ruzafa et al., 2013).

Echinometra vanbrunti (Fig. 11). The presence of this species in the offerings is fairly common, it is the most abundant sea urchin found. A complete test, multiple test fragments; primary spines and disarticulated Aristotle's lantern have been found in 13 offerings. It has a geographic distribution from California, USA to Peru, Panama, and Ecuador, with a

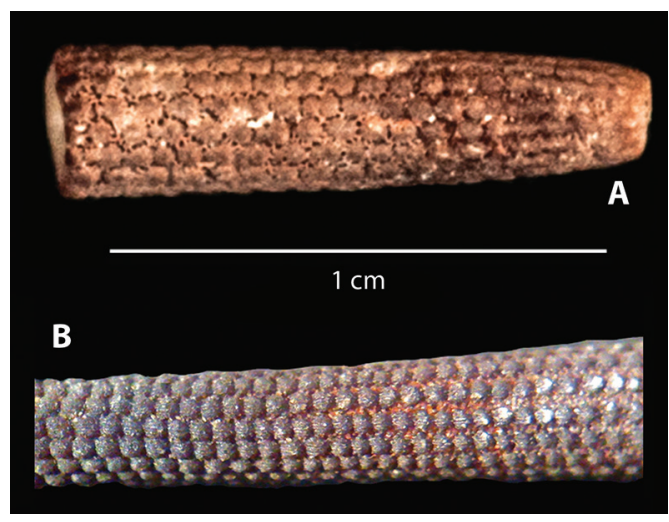

Fig. 10. Eucidaris thouarsii. A. Primary spine of an archaeological specimen; B. Primary spine of a nonarchaeological specimen. Scalebar: $1 \mathrm{~cm}$.

Fig. 10. Eucidaris thouarsii. A. Espina primaria de un espécimen arqueológico; B. Espina primaria de un espécimen no arqueológico. Barra de escala: $1 \mathrm{~cm}$.

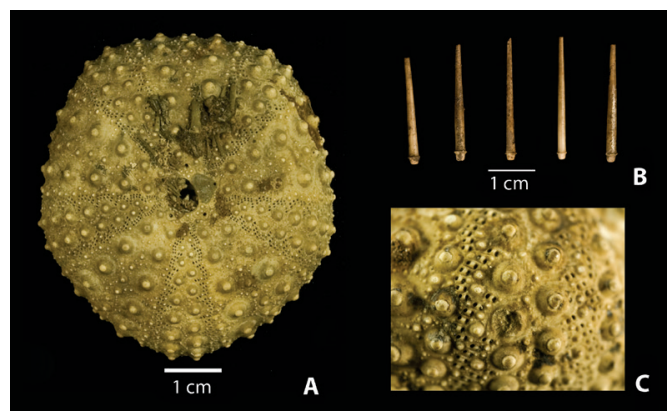

Fig. 11. Echinometra vanbrunti (archaeological specimen). A. Complete test; B. Primary spines; C. Ambulacral arc pores detail.

Fig. 11. Echinometra vanbrunti (espécimen arqueológico). A. Testa completa; B. Espinas primarias; C. Detalles de arco poros ambulacrales.

bathymetric distribution from 0 to $106 \mathrm{~m}$. It has been found in coral reefs, rocky or sandy bottoms (Pérez-Ruzafa et al., 2013).

Clypeaster speciosus (Fig. 12). The presence of this species in the offerings is rare. At least two complete tests have been found in two offerings (107 and 126). It has a geographic distribution from the Gulf of California to the Galapagos Islands, and its bathymetric distribution goes from 0 to $128 \mathrm{~m}$ (Ziesenhenne, 1937). It has been found on sandy bottoms (Pérez-Ruzafa et al., 2013). 


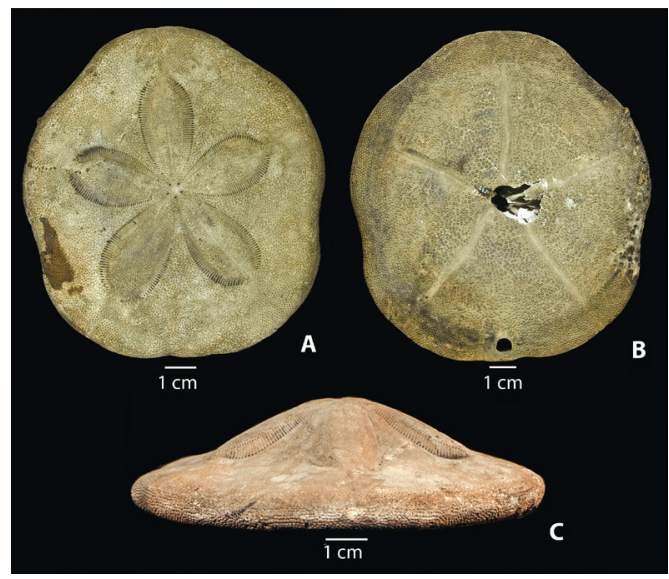

Fig. 12. Clypeaster speciosus (archaeological specimen). A. Aboral view; B. Oral view; C. Lateral view.

Fig. 12. Clypeaster speciosus (espécimen arqueológico). A. Vista aboral; B. Vista oral; C. Vista lateral.

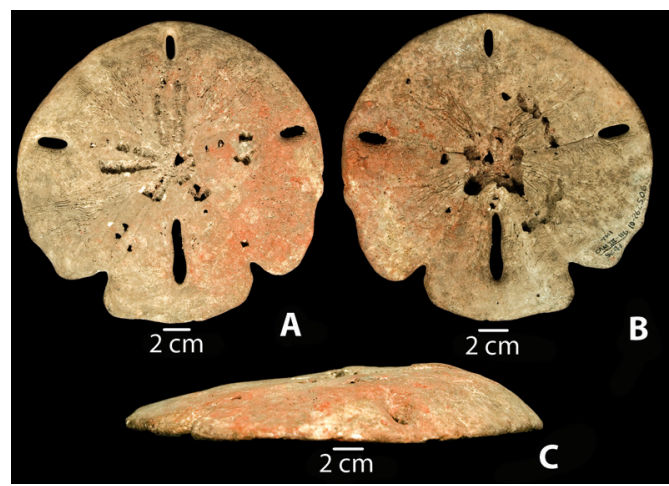

Fig. 13. Encope laevis (archaeological specimen). A. Aboral view; B. Oral view; C. Lateral view.

Fig. 13. Encope laevis (espécimen arqueológico). A. Vista aboral; B. Vista oral; C. Vista lateral.

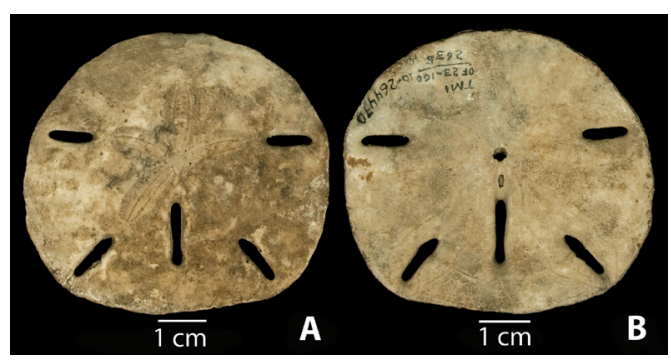

Fig. 14. Mellita quinquiesoerforata (archaeological specimen). A. Aboral view; B. Oral view; C. Lateral view. Fig. 14. Mellita quinquiesoerforata (espécimen arqueológico). A. Vista aboral; B. Vista oral; C. Vista lateral.
Encope laevis (Fig. 13). The presence of this species in the offerings is very rare; so far, only one complete test has been recovered in only one offering (Chamber 3). It has a geographic distribution in the Pacific coast of Nicaragua, Costa Rica, Panama, and Colombia, with a bathymetric distribution from 0 to $7 \mathrm{~m}$. It lives on sandy bottoms (Pérez-Ruzafa et al., 2013).

Mellita quinquiesperforata (Fig. 14). This species has been found in four offerings (88, 124, 141 and M). The presence of this species in these ritual deposits is frequent since numerous fragments have been found on them, proving that a lot of specimens were buried. It has a geographic distribution from Mexico to Colombia, Uruguay, and Brazil, with a bathymetric distribution from 0 to $180 \mathrm{~m}$. It lives on muddy or sandy bottoms (Pérez-Ruzafa et al., 2013).

Mellita notabilis (Fig. 15). The presence of this species in the offerings is very rare, only two fragments of this sand dollar have been found in offering 141. It has a geographic distribution from the Gulf of Mexico to El Salvador, Nicaragua, and Panama, with a bathymetric distribution from 0.5 to $0.9 \mathrm{~m}$. It has been found living in sandy substrates (PérezRuzafa et al., 2013).

Meoma ventricosa grandis (Fig. 16). The presence of this species in the offerings is rare, two whole specimens have been found in offering 126. It has a geographic distribution in the Pacific coast of Mexico, Costa Rica, Panama, and Galapagos Islands, with a bathymetric distribution from 0 to $36.6 \mathrm{~m}$ (Clark, 1948). It has been found on sandy bottoms (Pérez-Ruzafa et al., 2013).

\section{DISCUSSION}

From a taphonomic point of view, the skeleton of the echinoderms consists of multitude plates connected by soft tissue, which disintegrates within hours or days after their death (Kerr \& Twitchett, 2004). The lack of complete articulated echinoderm skeletons can be explained by the fact that the offerings have been exposed to inundation and desiccation 


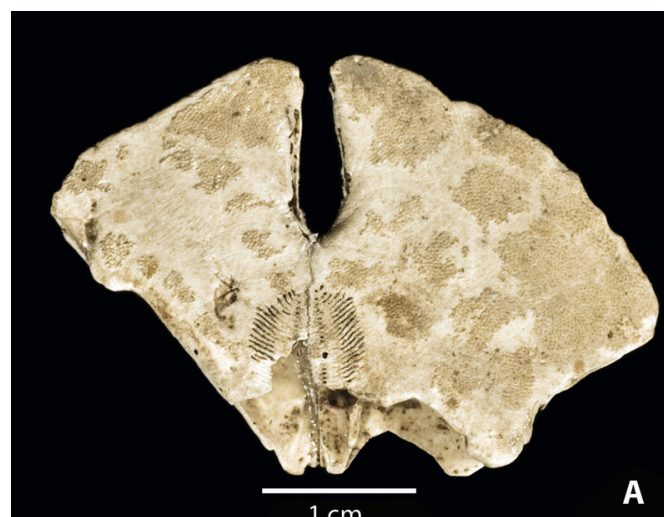

A

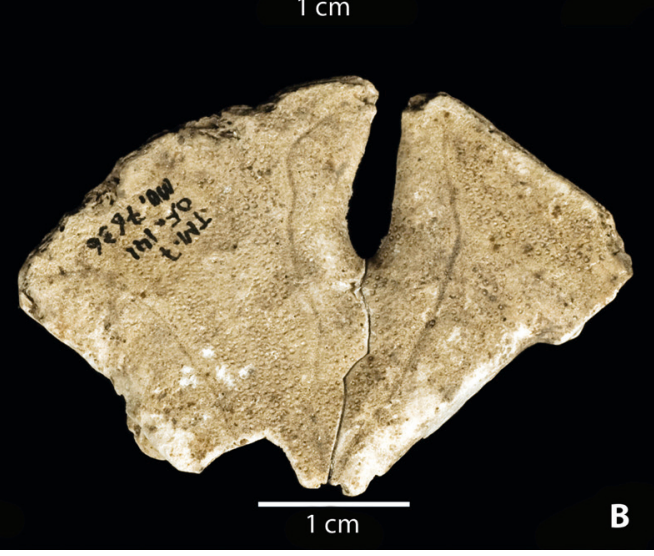

Fig. 15. Mellita notabilis (fragment of an archaeological specimen). A. Aboral view; B. Oral view; C. Lateral view. Fig. 15. Mellita notabilis (fragmento de espécimen arqueológico). A. Vista aboral; B. Vista oral; C. Vista lateral.

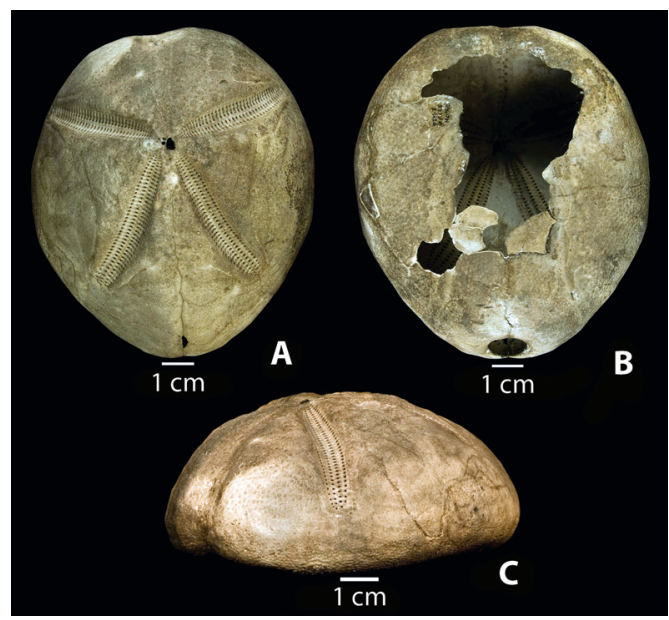

Fig. 16. Meoma ventricosa grandis (archaeological specimen). A. Aboral view; B. Oral view; C. Lateral view. Fig. 16. Meoma ventricosa grandis (espécimen arqueológico). A. Vista aboral; B. Vista oral; C. Vista lateral. process alternately due to the oscilation of the watertable, because the Basin of Mexico is a lacustrine zone, exposed to floods during the rainy season (Santoyo, Ovando, Mooser, \& León, 2005).

Of the six sea star species found in the offerings, Nidorellia armata followed by Pentaceraster cumingi were the dominant ones. This is probably explained by the sturdiness of their endoskeletons, which allows betterpreserved plates than those species with thinner plates (i. e. Luidia superba).

The sea stars found in the offerings are some of the most abundant species in the Pacific coast of Mexico at the present (Solís-Marín et al., 2013). So far, more than 50000 skeletal plates of sea stars have been counted (ZúñigaArellano et al., in press).

Ophiothrix rudis was the only ophiuroid species found in the offerings; it has a very weak skeleton, which is probably the reason why we only found its robust disk spines. It is uncertain if it was intentionally deposited in the offerings or if its presence is only circumstantial; that is to say that, by its habits, it could have associated with another marine animal included in the offerings (such as sponges and corals).

Among the abundant offerings buried in and around the Templo Mayor, the sixth constructive stage of this pyramid held the remains of complete tests and fragments of seven species of echinoids: Eucidaris thouarsii, Echinometra vanbrunti, Clypeaster speciosus, Encope laevis, Mellita quinquiesperforata, M. notabilis and Meoma ventricosa grandis. E. vanbrunti represents the most abundant echinoderm buried in the Templo Mayor (Solís-Marín et al., 2010). Because the Mexicas received tribute from other towns that they had dominated, probably some of these echinoid specimens came from the tribute payment of some group dominated by them or arrived in Tenochtitlan through commercial circuits, or as gifts (López Luján, 2005). The Mexica Empire at that time (AD 1469-1520) had conquered part of modern-day Mexico's territory (Guerrero, Oaxaca, and Chiapas states). C. speciosus record is very important because it indicates that they 
received materials from much farther to the north than normally considered (limits of the Michoacán and Guerrero states); it is important to mention that there are no organisms of this species deposited in the ENC, ICML, UNAM.

Almost all the echinoderm remains found at the Templo Mayor offerings correspond to adult specimens except for some $N$. armata plates and some Mellita tests fragment that clearly belong to juvenile specimens.

The Mexica buried echinoderms in their ritual deposits for at least a half-century. Moreover, species diversity increased over time as Mexica imperial power spread to the Pacific coast of Guerrero, Oaxaca, and Chiapas. It is known that during Ahuitzotl's reign ( $\mathrm{AD}$ 1486-1502), most of the conquests were on the Pacific Coast of Mesoamerica (Hassig, 1988). In those years, Cihuatlan, Tecpantepec, Ayotlan, Ometepec, Xoconochco, and Miahuatlan were converted into tributary provinces, while certain regions of Tehuantepec and Xochtlan were reconquered. Obviously, this afforded them unlimited access to the resources from the Pacific Ocean, both as a result of tribute and trade (López Luján et al., 2014).

The marine animals, including the sea urchins and sea stars (and very probably other classes of echinoderms) were brought alive to the site. Echinometra vanbrunti found in the offerings have pedicellariae vestiges on top of the test and some fragments of the Aristotle's lantern. It is believed that the transportation of the specimens was made using emissaries who ran very long distances and for a long time (on average they ran $30 \mathrm{~km}$ daily) (Solís-Marín et al., 2013), the nearest Pacific coast to Mexico City located in the State of Guerrero about $250 \mathrm{~km}$ away from it.

The scarcity of edible species, both animals and plants, indicates the clear interest on the part of Mexica priests in those animals to which they attributed profound religious or cosmological significance (López Luján et al., 2014). For example, predominating among fish were toxic species or those with rare anatomical features such as sharp teeth, strange bodies, bright colors, or strong dermal spines. Some echinoderm species found in the offerings have bright colors in life, for example deep red in Pentaceraster cumingi, yellow in Nidorellia armata or purple in Echinometra vanbrunti.

It is true that much work remains to be done, because the archaeological vestiges are still being found and even new offerings have been discovered.

\section{ACKNOWLEDGMENTS}

We thank Susana Guzmán and Berenit Mendoza Garfias (Laboratorio de Microscopía, IB, UNAM) for their technical support with the photos. We are grateful to Mirsa Islas Orozco and Carlos Conejeros Vargas for their photos as well as Ma. Esther Diupotex Chong and Alicia Durán (ICML, UNAM) for their technical support. We also thank Tomás Cruz Ruiz (PTM) for the separation and classification of the archaeological material. Finally, we would like to acknowledge Matthew Lovegrove, for reading and making comments on an early version of this manuscript.

\section{RESUMEN}

Entre 1978 y 1982 las ruinas del Templo Mayor de Tenochtitlan fueron exhumadas pocos metros al norte de la plaza central (Zócalo) de la Ciudad de México. El templo era el centro de la vida ritual de los mexicas y uno de los más famosos edificios ceremoniales de la época (siglos 15 y 16). Más de 200 ofrendas se han recuperado en el templo y edificaciones cercanas. Nosotros identificamos vestigios de 14 especies de equinodermos (en su mayoría como placas desarticuladas). Estos incluyeron seis especies de estrellas de mar (Luidia superba, Astropecten regalis, Astropecten duplicatus, Phataria unifascialis, Nidorellia armata, Pentaceraster cumingi), una especie de ofiuro (Ophiothrix rudis), dos especies de erizos de mar (Eucidaris thouarsii, Echinometra vanbrunti), cuatro especies de galletas de mar (Mellita quinquiesperforata, Mellita notabilis, Encope laevis, Clypeaster speciosus) y una especie de corazón de mar (Meoma ventricosa grandis). Datan de los reinados de Axayácatl (AD 1469-1481), Tízoc (AD 14811486), Ahuítzotl (AD 1486-1502), y Motecuhzoma II (AD 1502-1520). Aparentemente, la presencia de equinodermos en las ofrendas está relacionado con el mundo de Tlaloc (Dios de la lluvia y la tierra). Se cree que los organismos fueron utilizados por sacerdotes, como otros organismos marinos, para representar el inframundo acuático de la cosmovisión mesoamericana. 
Palabras clave: Echinodermata; Templo Mayor; Tenochtitlan; imperio mexica; periodo prehispánico; Mesoamérica; México.

\section{REFERENCES}

Alvarado, J. J., Solís-Marín F. A., \& Ahearn C. G. (2010). Echinoderm (Echinodermata) diversity in the Pacific coast of Central America. Marine Biodiversity, 40(1), 45-56.

Clark, H. L. (1948). A report of the echini of the warmer eastern Pacific, based on the collections of the "Velero III". Allan Hancock Pacific Expedition, 8(5): 225-351.

Clark, A. M., \& Downey, M. E. (1992). Starfishes of the Atlantic. London, UK. Chapman \& Hall.

González López, A., López Luján, L., Martín-Cao Martínez, C., Solís-Marín, F. A. \& Zúñiga-Arellano, B. (2011). Una estrella de mar encontrada en la ofrenda dedicatoria al monolito de Tlaltecuhtli, Templo Mayor de Tenochtitlan. Arqueología Mexicana, 19(112), 15-16.

Hassig, R. (1988). Aztec Warfare: Imperial Expansion and Political Control. Norman: University of Oklahoma Press.

Kalof, L. (2012). Oxford handbook of animal studies. New York: NY. Oxford University Press.

Kerr, T. J. V., \& Twitchett, R. J. (2004). Experimental decay and disarticulation of Ophiura texturata: implications for the fossil record of ophiuroids. In Balkema Press (Ed.), Proceedings of the 11th International Echinoderm Conference (pp. 439-446). München, Germany: Heinzeller, T. \& Nebelsick, J. H.

López Austin, A. \& López Luján, L. (2009). Monte Sagrado/Templo Mayor: El cerro y la pirámide en la tradición religiosa mesoamericana. Mexico City: INAH/UNAM.

López Austin, A. \& López Luján, L. (2017). State Ritual and Religion in the Sacred Precinct of Tenochtitlan. In D. L. Nichols \& E. Rodríguez-Alegría (Eds.), The Oxford Handbook of the Aztecs (pp. 605-621). New York: Oxford University Press.

López Luján, L. (2001). Tenochtitlán: Ceremonial Centers. In S. T. Evans \& D. L. Webster (Eds.), Archaeology of Ancient Mexico and Central America: An Encyclopedia (pp. 712-717). New York, NY: Garland Publishing.
López Luján, L. (2005). The offerings of the Templo Mayor of Tenochtitlan. Albuquerque, NM: UNM Press.

López Luján L., Chávez Balderas X., Zúñiga-Arellano B., Aguirre Molina A. \& Valentín Maldonado N. (2014). Entering the Underworld: Animal Offerings at the Foot of the Great Temple of Tenochtitlan. In B. S. Arbuckle \& S. A. McCarty (Eds.), Animals and Inequality in the Ancient World (pp. 33-61). Boulder, CO: University Press of Colorado.

Pérez-Ruzafa, A., Alvarado, J. J., Solís-Marín, F. A., Hernández, J. C., Morata, A., Marcos, C., ... \& Barraza, E. (2013). Latin America echinoderm biodiversity and biogeography: Patterns and affinities. In J. J. Alvarado \& F. A. Solís-Marín (Eds.), Echinoderm research and diversity in Latin America (pp. 511542). Berlin Heidelberg: Springer.

Santoyo, E., Ovando, S. E., Mooser, F., \& León, E. (2005). Síntesis geotécnica de la cuenca del Valle de México. Mexico City: TGC Geotecnia.

Solís-Marín, F. A., Honey-Escandón, M. B., HerreroPérezrul, M. D., Benitez-Villalobos, F., DíazMartínez, J. P., Buitrón-Sánchez, B. E., ... \& Durán-González, A. (2013). The echinoderms of Mexico: biodiversity, distribution and current state of knowledge. In J. J. Alvarado \& F. A. Solís-Marín (Eds.), Echinoderm research and diversity in Latin America (pp.11-65). Berlin Heidelberg: Springer.

Solís-Marín, F. A., Laguarda-Figueras, A., Martínez-Melo, A., Celaya Hernandez, E. V., Velasquez-Castro, N., Barrera-Rivera, J. A., ... \& Valentín-Maldonado, N. (2010). Echinoderm remains in the offerings of the Great Temple of the Aztecs. In Echinoderms: Durham. Proceedings of the 12th International Echinoderm Conference (pp. 77-79). Leiden: Balkema.

Thuy, B., \& Stöhr, S. (2016). A New Morphological Phylogeny of the Ophiuroidea (Echinodermata) Accords with Molecular Evidence and Renders Microfossils Accessible for Cladistics. PloS one, 11(5), e 0156140.

Ziesenhenne, F. C. (1937). The Templeton Crocker Expedition. X. Echinoderms from the West Coast of Lower California, the Gulf of California and Clarion Island. Zoologica, 22(15): 209-239.

Zúñiga-Arellano, B., López Luján, L., Caballero-Ochoa, Solís-Marín, A. F., Martín Cao Romero, C., \& Hernández Díaz, Y. Q. (n.d.). Estrellas de mar en las ofrendas del Templo Mayor de Tenochtitlan. In L. López Luján \& X. Chávez Balderas (Eds.), Al pie del Templo Mayor de Tenochtitlan: ensayos en honor a Eduardo Matos Moctezuma. Mexico City: El Colegio Nacional, in press. 